\title{
Hereditary Hydronephrosis in C57L/MsNrs Mice
}

\author{
Kaoru TAKANO, Atsuo OGURA, Osamu SUZUKI, Yoko NOGUCHI, \\ Yoshie YAMAMOTO, Shigetoshi KUROSAWA, \\ and Toshihiko ASANO \\ Department of Veterinary Science, National Institute of Health, 2-10-35 \\ Kamiosaki, Shinagawa-ku, Tokyo 141, Japan
}

(Received 24 July 1992/Accepted 8 September 1992)

\begin{abstract}
Inbred C57L/MsNrs mice (66 males and 72 females) maintained at the National Institute of Health, Japan, were examined grossly for hydronephrosis. Unlike the hydronephrotic strains of mice reported so far, C57L mice showed no sex-related difference in the incidence $(62 \%$ in males and $75 \%$ in females ; P $>0.05)$ and severity of hydronephrosis. The right kidney was more severely affected than the left kidney in both sexes. Age appeared to have no influence on the incidence. - KEY WORDS : C57L, hydronephrosis, kidney, mouse
\end{abstract}

Hereditary hydronephrosis has been reported in several inbred strains of mice $[1,4,5$, 7]. Hydronephrosis in these species is characterized by 1) a higher incidence and more rapid progression in males than in females and 2) a higher incidence in the right kidney than in the left kidney.

Recently we have found a high incidence of hydronephrosis in C57L/MsNrs mice, which do not show any sex-related differences in the incidence or severity of the disease. Here we report that $\mathrm{C} 57 \mathrm{~L}$ mice maintained in our laboratory may also be useful for work on hereditary hydronephrosis.

Sixty-six male and 72 female C57L/MsNrs mice were used in this study. The production colony was populated from the National Institute of Radiological Sciences (Japan) in 1983, and has been maintained by brother-sister mating (24 generations). Groups of 3-5 mice were housed in stainless steel cages with wood chip bedding under a specific-pathogen-free condition. The room was kept at $22 \pm 2^{\circ} \mathrm{C}$ with a photoperiod of $14 \mathrm{~h}: 10 \mathrm{~h}$ (light : dark). They were provided with a commercial diet (CMF, Oriental Yeast Co., Tokyo) and tap water ad libitum. At the age of $50-70,100-140$ or 170-200 days, the animals were anesthetized with ether and sacrificed by cervical dislocation. Mice from at least three litters were used for each age group. The severity of hydronephrosis was classified into three categories by gross examination; - , no or very slight pelvic dilatation; + , apparent pelvic dilatation $;++$, apparent pelvic dilatation accompanied by an increase in the volume of the kidney. The left and right kidneys were compared with each other in a cross section to see which side hydronephrosis affected more severely. DDD mice (44 males and 38 females), in which an extremely high incidence of hydronephrosis has been reported [4], were maintained under the same conditions and examined as well. Data were analyzed using Fisher's exact probability test.

All the C57L and DDD mice examined were normal in appearance regardless of the severity of hydronephrosis. There were no abnormalities in organs or tissuse other than the kidney and ureter. Severe hydronephrosis was usually associated with dilatation of the upper ureter. The incidence of hydronephrosis in C57L and DDD mice is summarized in Table 1 . In C57L mice, there was no significant difference in the frequency of hydronephrosis between the sexes $(P>0.05)$. In general, the right kidney was 
Table 1. Incidence of hydronephrosis (HN) in C57L and DDD mice

\begin{tabular}{|c|c|c|c|c|}
\hline $\begin{array}{l}\text { Strain } \\
\text { and } \\
\text { sex }\end{array}$ & Age (day) & $\begin{array}{l}\% \text { (no.) of } \\
\text { mice with } \\
\mathrm{HN}\end{array}$ & $\begin{array}{l}\% \text { (no.) of } \\
\text { mice with } \\
\text { severe } \mathrm{HN}^{1}\end{array}$ & $\begin{array}{c}\% \text { (no.) of mice } \\
\text { asymmetrically } \\
\text { affected (right }>\text { left) }\end{array}$ \\
\hline C57L & $50-70$ & $54(13 / 24)^{a, 1}$ & $15(2 / 13)$ & $92(12 / 13)$ \\
\hline \multirow[t]{3}{*}{ males } & $100-130$ & $60(15 / 25)^{\mathrm{b}, \mathrm{J}}$ & $40(6 / 15)$ & $80 \quad(12 / 15)$ \\
\hline & $170-200$ & $77(13 / 17)^{c, k}$ & $6(1 / 13)$ & $69(9 / 13)$ \\
\hline & Total & $62(41 / 66)^{\mathrm{d}, 1}$ & $22(9 / 41)^{q}$ & $80 \quad(33 / 41)$ \\
\hline C57L & $50-70$ & $63(20 / 30)^{a^{\prime}, m}$ & $35(7 / 20)$ & $85(17 / 20)$ \\
\hline \multirow[t]{3}{*}{ females } & $100-130$ & $76(16 / 21)^{b^{\prime}, n}$ & $31 \quad(5 / 16)$ & $100(16 / 16)$ \\
\hline & $170-200$ & $86(18 / 21)^{c^{\prime}, o}$ & $33(6 / 18)$ & $83(15 / 18)$ \\
\hline & Total & $75(54 / 72)^{d^{\prime}, p}$ & $33(18 / 54)^{q^{\prime}}$ & $89 \quad(48 / 54)$ \\
\hline DDD & $50-70$ & $100(16 / 16)^{e, i^{\prime}}$ & $50(8 / 16)$ & $75(12 / 16)$ \\
\hline \multirow[t]{3}{*}{ males } & $100-130$ & $100(16 / 16)^{f, J^{\prime}}$ & $69(11 / 16)$ & $94(15 / 16)$ \\
\hline & $170-200$ & $100(12 / 12)^{\mathrm{g}, \mathbf{k}^{\prime}}$ & $25(3 / 12)$ & $83(10 / 12)$ \\
\hline & Total & $100(44 / 44)^{\mathrm{h}, \mathrm{1}^{\prime}}$ & $50(22 / 44)^{r}$ & $84(37 / 44)$ \\
\hline DDD & $50-70$ & $40(6 / 15)^{\mathrm{e}^{\prime}, \mathrm{m}^{\prime}}$ & $17(1 / 6)$ & $100(6 / 6)$ \\
\hline \multirow[t]{3}{*}{ females } & $100-130$ & $54(7 / 13)^{f^{\prime}, n^{\prime}}$ & $0(0 / 7)$ & $100(7 / 7)$ \\
\hline & $170-200$ & $60(6 / 10)^{\mathbf{g}^{\prime}, o^{\prime}}$ & $0(0 / 6)$ & $83(5 / 6)$ \\
\hline & Total & $50(19 / 38)^{h^{\prime}, p^{\prime}}$ & $5(1 / 19)^{r^{\prime}}$ & $95(18 / 19)$ \\
\hline
\end{tabular}

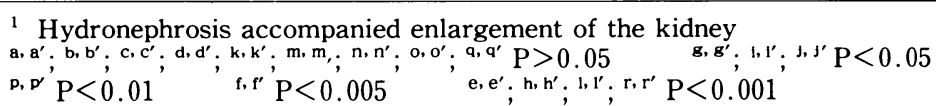

more severely affected than the left kidney. The proportion of animals with severe hydronephrosis $(++)$ varied greatly among groups $(6-29 \%)$ and did not differ between the sexes $(\mathrm{P}>0.05)$. In contrast to $\mathrm{C} 57 \mathrm{~L}$ mice, DDD mice showed an apparent sex-related difference in the incidence $(P<0.05-0.001$, depending on age group), as has already been reported [4] ; all DDD males examined were affected by hydronephrosis, whereas half of the females remained unaffected. As in $\mathrm{C} 57 \mathrm{~L}$ mice, the right kidney of DDD mice was more severely affected than the left kidney in both sexes. Here again, there was great variation among groups in the percentage of severe hydronephrosis $(0-69 \%)$, but a sex-related difference was apparent $(\mathrm{P}<0.001)$. When the incidence of hydronephrosis was compared between corresponding groups of $\mathrm{C} 57 \mathrm{~L}$ and $\mathrm{DDD}$ mice, significant differences were found in groups of 50-70 day-old males and 100-130 day-old males $(\mathrm{P}<0.005)$, with the DDD mice having a higher incidence. Examination with a greater number of animals would be necessary to determine strain differences more exactly. In male and female C57L mice and female DDD mice, the incidence of hydronephrosis tended to increase with age, but this change was not statistically significant.

We also examined the $\mathrm{C} 57 \mathrm{~L} / \mathrm{MsNrs}$ strain of mice maintained at the National Institute of Radiological Sciences, Japan, from which our $\mathrm{C} 57 \mathrm{~L} / \mathrm{MsNrs}$ mice were derived. This colony had a slight tendency to develop hydronephrosis $(<15 \%)$. At present we do not know why our C57L mice showed hydronephrosis more frequently than the original colony.

Although several different genes have been reported to participate in the onset of hydronephrosis in mice $[2,6]$, the mode of inheritance is not clearly understood. It is generally recognized that male mice have a significantly higher overall incidence than females $[1,4,5,7]$. According to Goto et al. [3], the onset and progression of hydronephrosis in DDD mice are closely correlated with the blood testosterone level. In C57L mice, neither the incidence nor the severity of the disease differed between the sexes. We have not yet measured the levels of blood testosterone in C57L mice, but it is very unlikely that males and females would have the same testosterone level. Therefore, the mechanism (s) accounting for hydronephrosis in C57L mice may not be associated with male hor- 
mones. Since age did not appear to influence the incidence or severity of the disease, the fate of individuals may be determined during their neonatal or embryonicstages. More detailed studies on hydronephrosis in C57L mice, e.g. , those using histopathological and genetic methods, would provide more information on the onset and develooment of hydronephrosis in laboratory mice.

We Thank Dr. T. Matsumoto and Mr. F. Nagasawa, National Institute of Radiologcal Sciences, for their cooperation in the research.

\section{References}

[1] Collins, G. R., Goodheart, C. R., and Henson, D. (1972). Lab. Anim. Sci., 22, 333-338.

[2] Goto, N., Nakajima, Y., Onodera, T., and Imamura, K. (1984). Lab. Anim., 18, 22-25.

[3] Goto, N., Nakajima, Y., Imamura, K., and Yoshida, T. (1985). Lab. Anim., 19, 85-88.

[4] Nakajima, Y., Imamura, K., Onodera, T., Motoi, Y., and Goto, N. (1983). Lab. Anim., 17, 143-147.

[5] Taylor, D. M. and Fraser, H. (1973). Lab. Anim., 7, 229-236.

[6] Wallace, M. E. and Spickett, S. G. (1967). J. Med. Gen. , 4, 73-82.

[7] Wright, J. R. and Lacy, P. E. (1988). J. Comp. Path., 99, 449-454.

\section{C57L/MsNrsマウスにおける水腎症の発症}

高野薫・小倉淳郎・鈴木 治・野口洋子

山本美江・黒沢重利・浅野敏彦

国立予防衛生研究所獣医科学部

国立予防衛生研究所に維持されるC $57 \mathrm{~L}$ 系マウス (雄 66 頭, 雌 72 頭) における水腎症の発生について 調べた。今までに報告された水腎症マウス系統と異な り, 雄雌で発症率に差はみられず（雄 $62 \%$, 雌 $75 \%$;
$\mathrm{P}>0.05)$, また重症度でも差は認められなかった。雌 雄とも右側堅䑏がより高度に冒されていた。年齢と発 生頻度とは関連が無かった。 